\title{
ACIDIFICATION OF TILL IN NORTHERN FINLAND: EXPERIMENTAL STUDY
}

\author{
RISTO AARIO and VESA PEURANIEMI
}

AARIO, RISTO and PEURANIEMI, VESA 1996. Acidification of till in Northern Finland: experimental study. Bull. Geol. Soc. Finland 68, Part I, $50-00$.

The acid neutralizing capacity of till and some effects promoted by increasing acidity, were studied in a number of tills in northern Finland. $\mathrm{pH}$ profiles were measured in the field and acid neutralizing capacity (ANC mmol/100 g sample) in the laboratory as a function of the varying acidity in solution. The concentrations of $\mathrm{Al}, \mathrm{Ca}, \mathrm{Mg}, \mathrm{Fe}, \mathrm{K}, \mathrm{Mn}, \mathrm{Zn}, \mathrm{Cu}$ and $\mathrm{Sr}$ in solutions were also analyzed. The results are presented in the form of graphs of ANC versus final $\mathrm{pH}$ of the solution and element concentration versus final $\mathrm{pH}$. The total concentrations of the major elements were analyzed by XRF and those of trace elements by AAS.

The $\mathrm{pH}$ measured in the test pits was lowest just below the ground surface, and rose rapidly to a value of 6 at a depth of about $1 \mathrm{~m}$ and then it remained more or less constant with depth. The laboratory analyses clearly suggest that the acid neutralizing capacity of till correlates well with sample depth. The ANC values, which represent the fast-working part of the capacity, are higher in the surficial parts owing to the easily soluble aluminium and iron hydroxides which have their origin in the weathering processes. The experiments resemble acid rain conditions, where the higher $\mathrm{pH}$-level buffers are unable to neutralize the increase in acidity immediately, so that lower $\mathrm{pH}$-level buffering processes such as $\mathrm{Al}$ and Fe hydroxide buffers come into play. The situation can be hazardous for both forests and surface water.

Keywords: environmental geology, till, acidification, $\mathrm{pH}$, buffers, neutralization, chemical elements, experimental studies, Northern Finland.

Risto Aario and Vesa Peuraniemi: Institute of Geosciences and Astronomy, University of Oulu, Linnanmaa, 90570 Oulu, Finland. 


\section{INTRODUCTION}

The present survey was carried out in connection with the SOMA (=Applied Surficial Geology) project financed by the Finnish Academy (Aario, 1984), which covered some hundreds of test pits made by tractor excavators in an area of about $100000 \mathrm{~km}^{2}$ in northern Finland (Fig. 1). The six sub-areas, which were chosen, represent areas of different climate, bedrock and till types and till landforms, including cover moraine, drumlins, Rogen moraines, radial moraines,

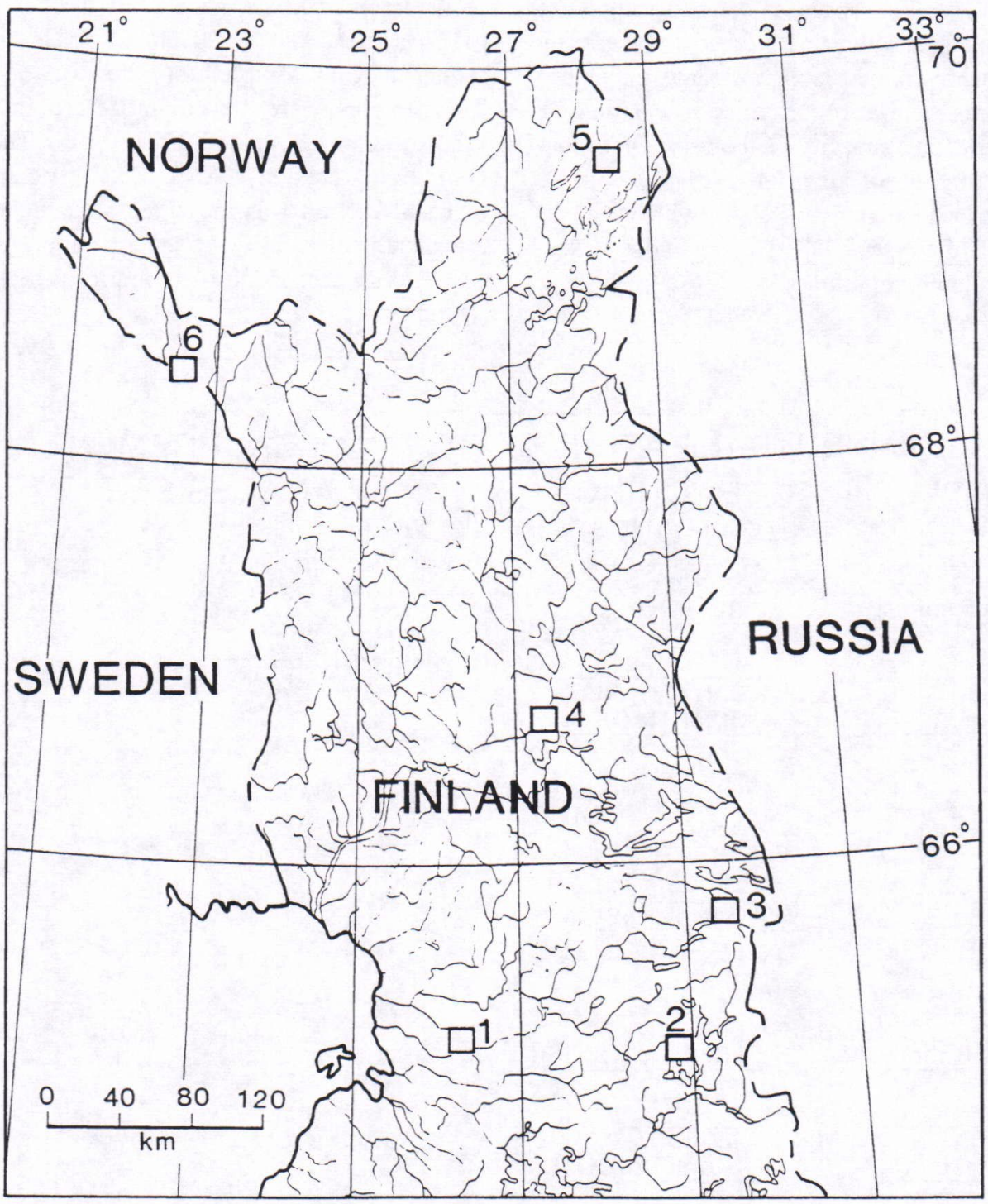

Figure 1. The area studied here covers about $100000 \mathrm{~km}^{2}$ in northern Finland. The numbers refer to sites of detailed investigations. 1: Korppikangas, an end moraine hill, 2: Kianta moraine, an interlobate train of morainic hummocks, 3: Säynäjäluoma drumlin, 4: Rogen ridge of Tohmo, 5: morainic assemblages at Sevettijärvi, cover moraine and morainic hummocks, 6: Pulju moraine at Kaaresuvanto. 
hummocky disintegration moraines and end moraines (closer description in Aario, 1990).

The purpose of the survey was to study the effects of the natural postglacial acidification of tills in the target areas. Since the test pits were commonly excavated to a depth of 3-4 $\mathrm{m}$ it has been possible to obtain wide-scale areal information of thick till sequnces, in contrast to previous studies in Finland which have been concentrated predominantly on the soil horizons. Laboratory experiments were also performed to examine the acid neutralizing capacity of the tills. These matters are currently of great interest because of the human-induced increase in acidity, which is threatening the forests and lakes in Finland and is of great economic importance.

\section{METHODS}

An aerial photo interpretation was first performed in order to map the glacial features, their origins and their relationships to the ice flow patterns. In the field, the texture, structure and lithology of the till in the test pits were studied with reference to the genesis of the landforms. $\mathrm{pH}$ was measured at $20 \mathrm{~cm}$ intervals and the sequences were sampled for laboratory analyses. The samples were sieved into three fractions: $<0.06,0.06-0.25$ and $0.25-0.6 \mathrm{~mm}$. The acid neutralizing capacity (ANC meq/100 g sample) of each fraction was measured as a function of the increasing acidity of the solution.This was accomplished by adding sulphuric acid, $\mathrm{H}_{2} \mathrm{SO}_{4}$,

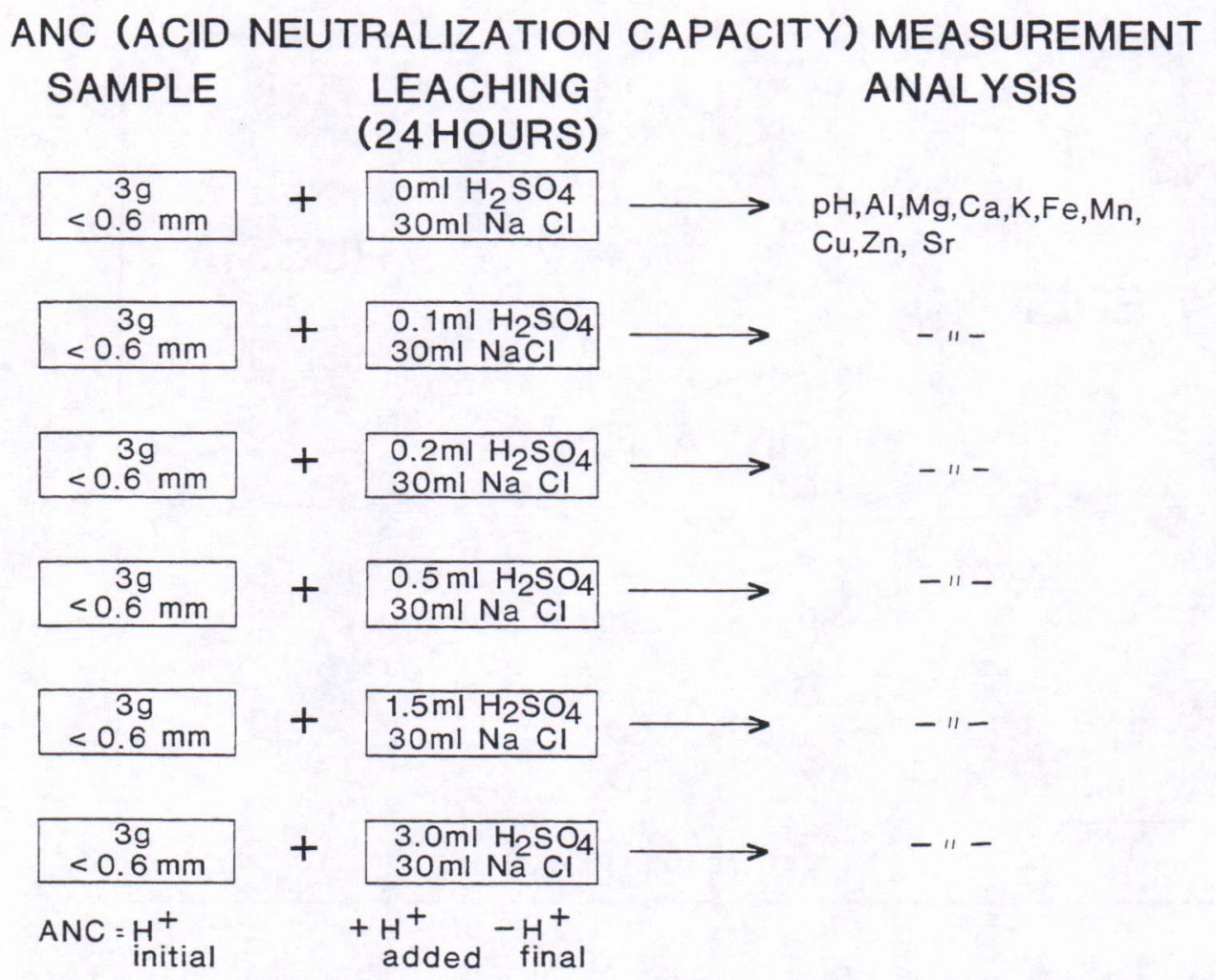

Figure 2. Procedures related to the ANC measurements. 
in the solution (Fig. 2). The concentrations of $\mathrm{Al}, \mathrm{Ca}, \mathrm{Mg}, \mathrm{Fe}, \mathrm{K}, \mathrm{Mn}, \mathrm{Zn}, \mathrm{Cu}$ and $\mathrm{Sr}$ in the solution were also analyzed. As the samples had a very low content of humus, no pretreatment was performed to remove it. The principles of the method used are those introduced by Wyatt (1984; cf. also Räisänen and Lahermo 1985).

This procedure also served to show the effect of grain size on the parameters measured. Most of the analyses were performed on the fraction $<0.6$ $\mathrm{mm}$, however, to give an indication of the bulk ANC of the till. As the experiments are based on a 24 hour leaching, one should remember that the measured ANC value tends to represent the fastworking part of the total capacity, a part which is particularly interesting in terms of acid rain conditions. The total element contents of the till sequences were analyzed by X-ray fluorescence for the major elements and by AAS for the trace elements. The total dissolution with a mixture of strong acids was used before AAS analysis.

\section{RESULTS}

As already mentioned, the survey included tills and till landforms of different types located in different climatic zones and on different types of bedrock. The properties proved to be quite consistent between the different test pits and different areas. It seems that even though the parent material has some effect on the measured properties the weathering processes were more or less similar troughout the area, being those of podzolic soil formation, and these had the dominant effect on the alteration characteristics. Because of the great similarity in $\mathrm{ANC}, \mathrm{pH}$ and extractability of elements between the different profiles, only some representative examples are shown as graphs in Figs. 3-16.

\section{pH}

An example of the $\mathrm{pH}$ measurements is given in Fig. 3. There is a general trend for the $\mathrm{pH}$ measured in the profiles to be lowest in the uppermost sample taken from just below the ground surface. It rises rapidly by about one unit at a depth of $1 \mathrm{~m}$ and remains then more or less constant below $1 \mathrm{~m}$. Variations in $\mathrm{pH}$ do occur, however, and there are also irregularities due to the layered structures of some tills.

\section{Total element contents}

The total element analyses show no great differences between sample depths deeper than $1 \mathrm{~m}$. Enrichment of $\mathrm{Al}$ and $\mathrm{Fe}$ in particular could frequently be seen in the upper parts of the profile due to soil formation. Some trace elements, such as $\mathrm{Zn}$ and $\mathrm{Cr}$ at Korppikangas (Fig. 4), show a marked enrichment along with Al and $\mathrm{Fe}$. Deeper down in the profiles one can see that $\mathrm{Ca}$ increases slightly with depth. All these features can be attributed mostly to the leaching

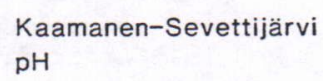

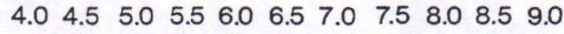

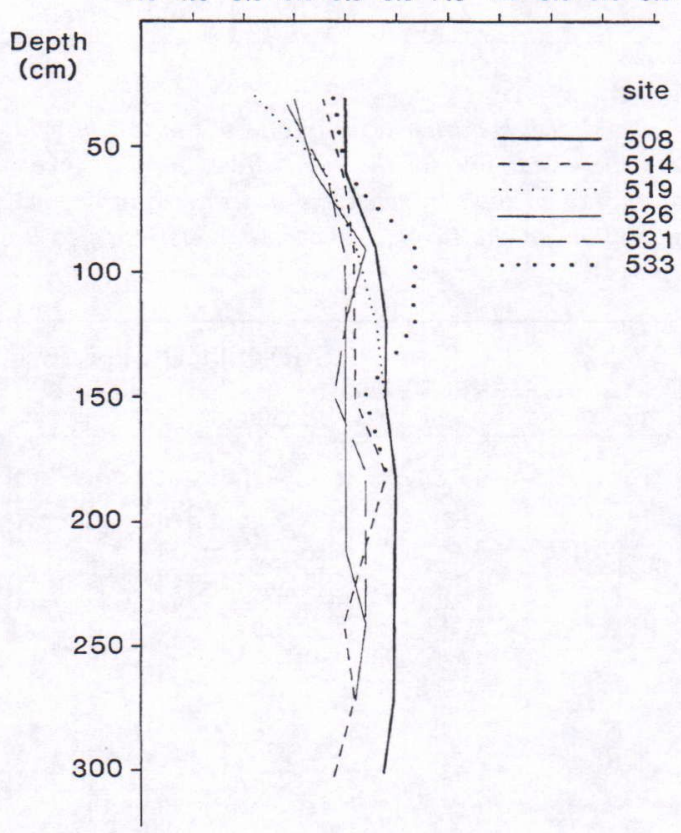

Figure 3. pH graphs for till profiles in the KaamanenSevettijärvi area. 
and re-precipitation related to soil formation processes.

There is a marked difference in geochemistry between profiles from Korppikangas and Sevetti- järvi (Figs. 4-5). The contents of $\mathrm{Mg}, \mathrm{Ca}, \mathrm{Fe}, \mathrm{Cu}$, $\mathrm{Ni}, \mathrm{Co}, \mathrm{Cr}$ and $\mathrm{Zn}$ at Sevettijärvi are at higher level than those at Korppikangas. On the contrary the contents of $\mathrm{Na}$ and $\mathrm{K}$ at Korppikangas are at higher

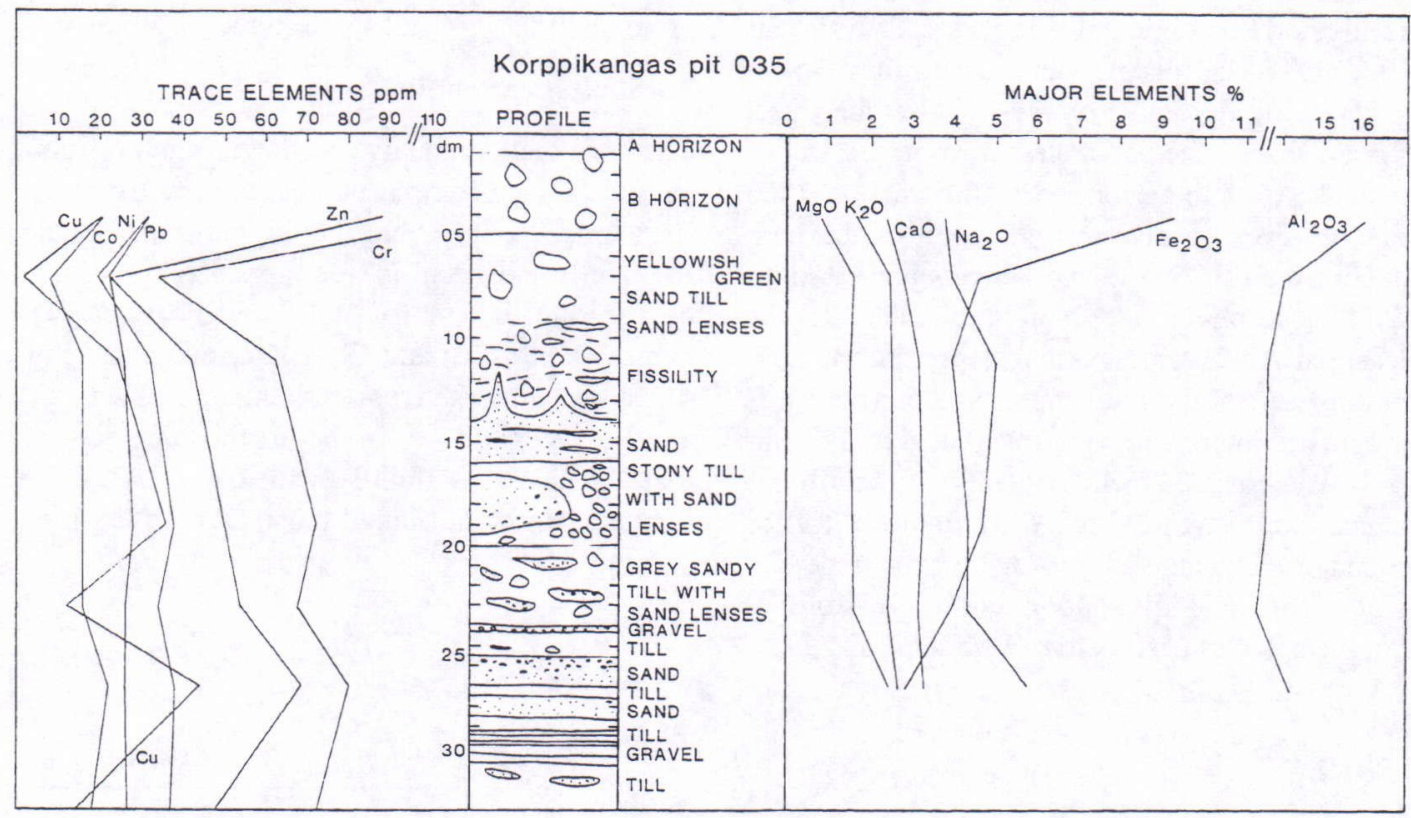

Figure 4. Till sequence seen in one of the test pits dug in Korppikangas, an end moraine hill. This pit was dug into the distal part of the hill, where the sequence was characterized by layers of flow till, but the layering seems not to have effected the measured parameters very much. There is an obvious enrichment of iron and aluminium at the surface. Some trace elements, in this case $\mathrm{Zn}$ and $\mathrm{Cr}$ are also enriched in the upper parts.

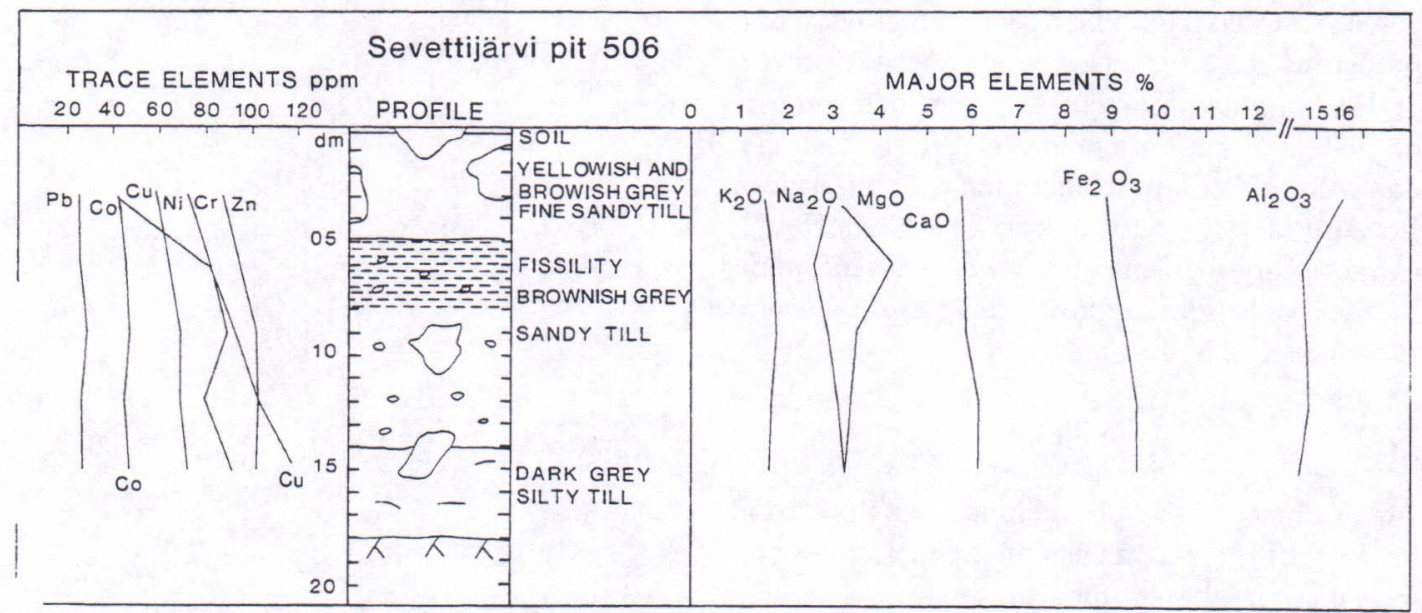

Figure 5. Till sequence seen in one of the test pits dug in a cover moraine area of Sevettijärvi. 
level than those at Sevettijärvi. The clay fraction of till at Sevettijärvi contains more chlorite and amphibole than that at Korppikangas. This difference is due to the different rock types in bedrock: the Sevettijärvi site is situated in the area of early Proterozoic greenstone formation and Korppikangas in the area of early Proterozoic metasedimentary schists. The increasing $\mathrm{Cu}$ content with depth at Sevettijärvi (Fig. 5) most probably is an indication of a local $\mathrm{Cu}$ mineralization in the greenstone bedrock, which has not yet been found.

\section{ANC}

ANC graphs of different grain sizes are shown in Fig. 6 and an example of those produced for the vertical till profiles in Fig. 7. As one could anticipate, the ANC values are higher in the finer fractions of the deposits. This is evidently due to the large amount of adsorbed exchangeable cations on the clay mineral surfaces and to those more loosely bound to the minerals. A large part of the clay-size material in tills in Finland derives from reworked preglacial weathering products (cf. also Wilson,1986), with a high exchange capacity, but the finest fractions do not necessarily give the best indication of the total ANC. The values for grain size $<0.6 \mathrm{~mm}$ at different depths show very clearly that the ANC values are higher in the uppermost parts of the till layers

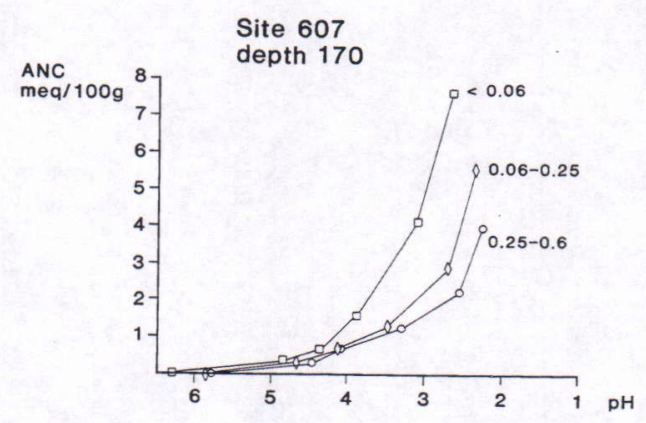

Figure 6. ANC graphs for different grain sizes of till at site 607, Tohmo Rogen ridge.

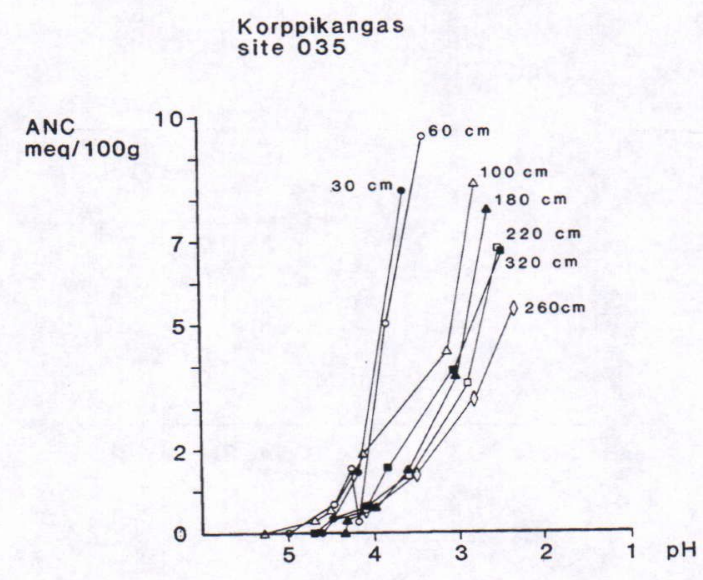

Figure 7. ANC graphs for different depths of a till profile at Korppikangas end moraine hill.

and decrease downwards (Fig. 7). The curves are closer to each other at depths below $1.5 \mathrm{~m}$. This shows that the effects of the podzolisation usually reach down to this depth (cf. also Olsson and Melkerud, 1989; Soveri, 1989, p. 167; Aario and Peuraniemi, 1991a), although they sometimes were found to continue down to depths of more than $2 \mathrm{~m}$.

\section{$\mathrm{H}_{2} \mathrm{SO}_{4}$ soluble elements}

The easily soluble elements were analyzed by AAS after leaching the samples for 24 hours, so that the results show the fast response related to the increase in acidity. Aluminium is dissolved from the upper parts of the profiles in greater quantities and at higher $\mathrm{pH}$ (cf. also Derome, 1989) than deeper down (Fig. 8), where it is more firmly bound in the lattices of silicate minerals. Large amounts of $\mathrm{H}_{2} \mathrm{SO}_{4}$ soluble $\mathrm{Al}$, a characteristic of the acid soils (e.g. Kennedy, 1986, pp. 155-157), exist down to a depth of 1 -1.5. $\mathrm{m}$, and the $\mathrm{H}_{2} \mathrm{SO}_{4}$ soluble $\mathrm{Fe}$ behaves in a similar manner (Fig. 9).Pronounced precipitation of ferric iron in the B horizon may alter the figure in places, but it is already possible to see that the easily soluble $\mathrm{Fe}$ and $\mathrm{Al}$ hydroxides are more or less responsible for the higher ANC at 


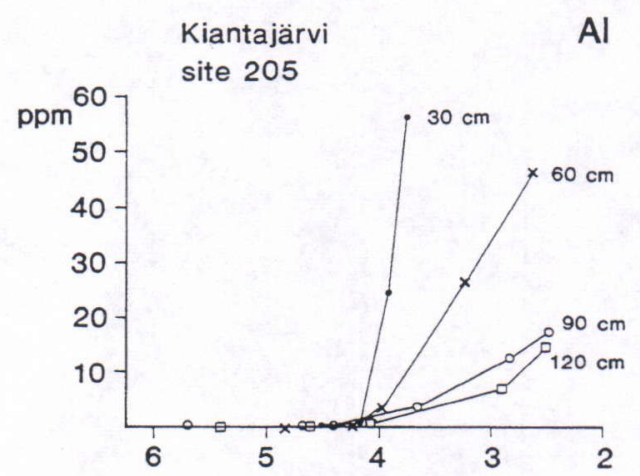

$\mathrm{pH}$

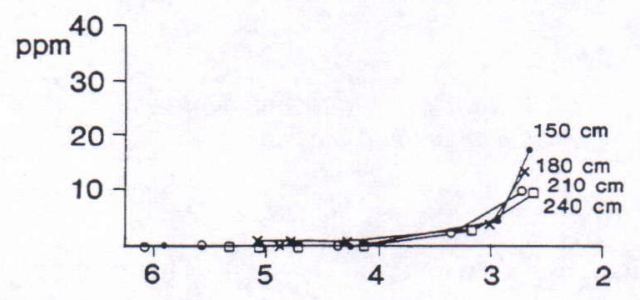

Figure 8. Dissolved $A l$ versus $\mathrm{pH}$ at different depths in the till profile at site 205, Kiantajärvi, morainic hummock.

the upper parts of the profiles (cf. Vuorinen and Lahermo 1987; Aario and Peuraniemi 1991b; Petäjä-Ronkainen et al., 1992). These elements can occur as variously bounded to mineral par-

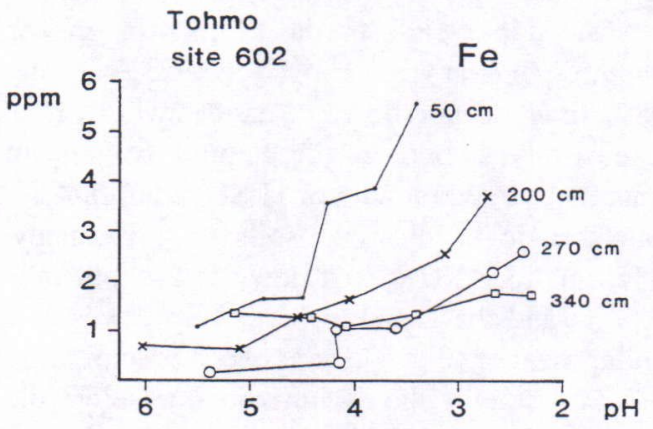

Figure 9. Dissolved $\mathrm{Fe}$ versus $\mathrm{pH}$ at different depths in the till profile at site 602, Tohmo Rogen ridge.
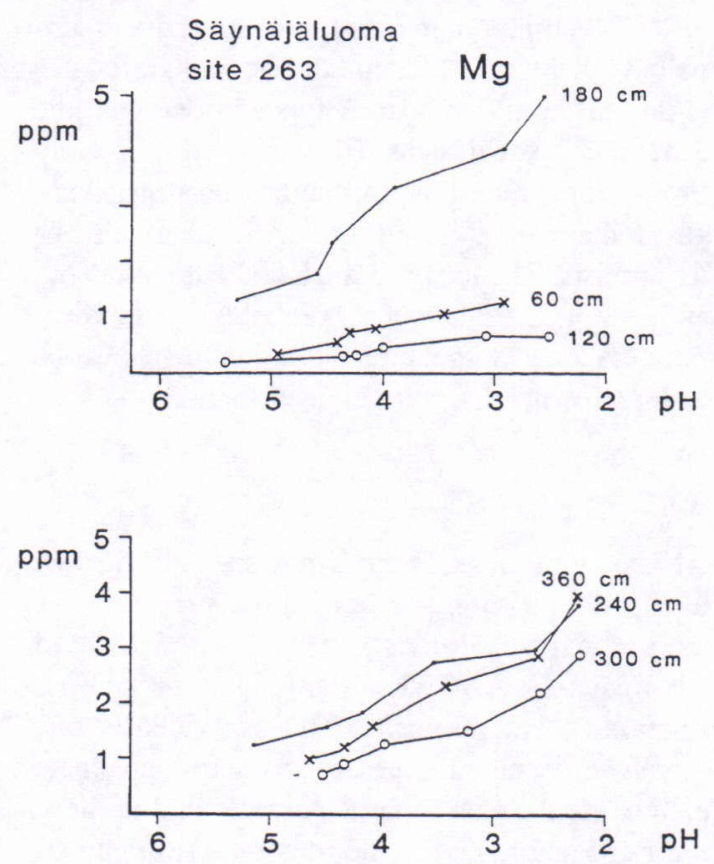

Figure 10. Dissolved $\mathrm{Mg}$ versus $\mathrm{pH}$ at different depths in the till profile at site 263, Säynäjäluoma drumlin.

ticles and their surfaces (cf. Ottesen et al., 1989; Räisänen et al., 1989).

Magnesium, $\mathrm{Ca}, \mathrm{K}$ and $\mathrm{Sr}$ seem to have been leached out from the upper parts (Figs. 10-13), but there seems not to occur any re-precipitation lower

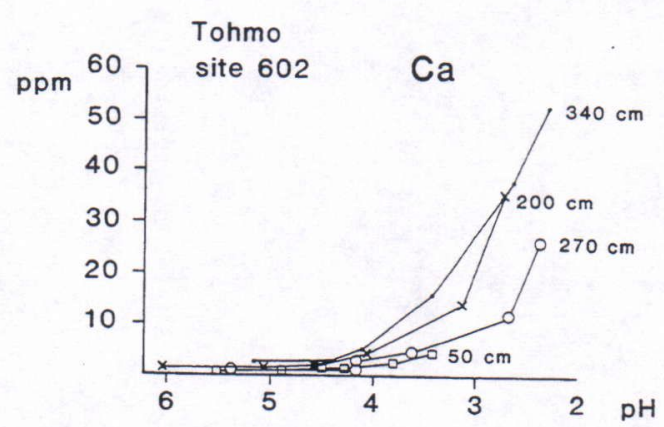

Figure 11. Dissolved Ca versus pH at different depths in the till profile at site 602, Tohmo Rogen ridge. 

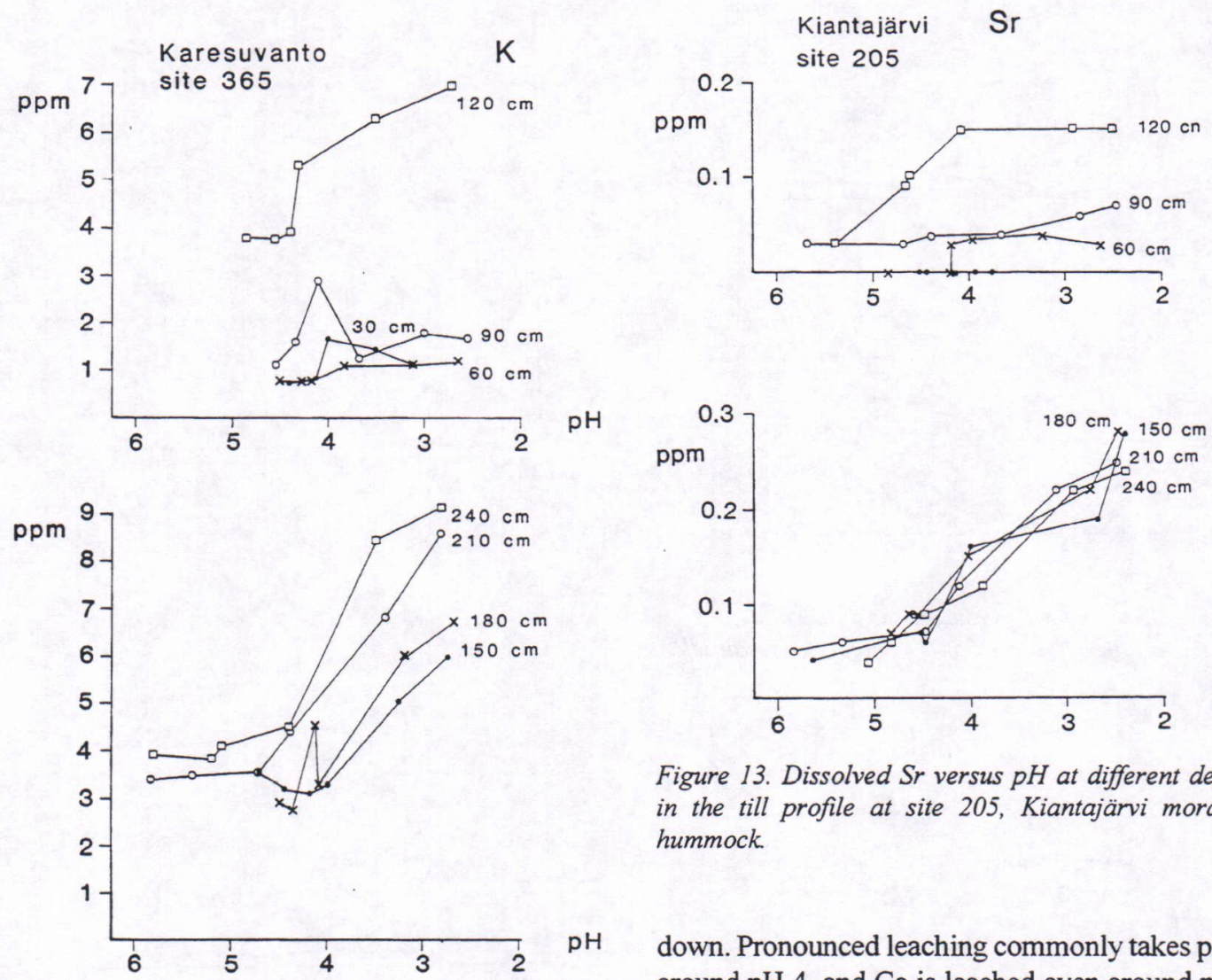

$\mathrm{pH}$

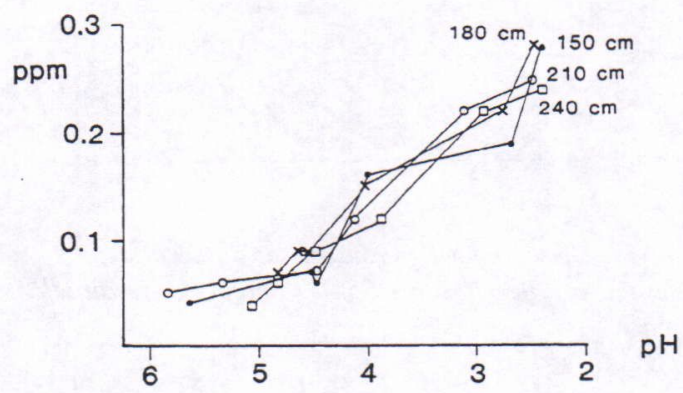

Figure 13. Dissolved Sr versus pH at different depths in the till profile at site 205, Kiantajärvi morainic hummock.

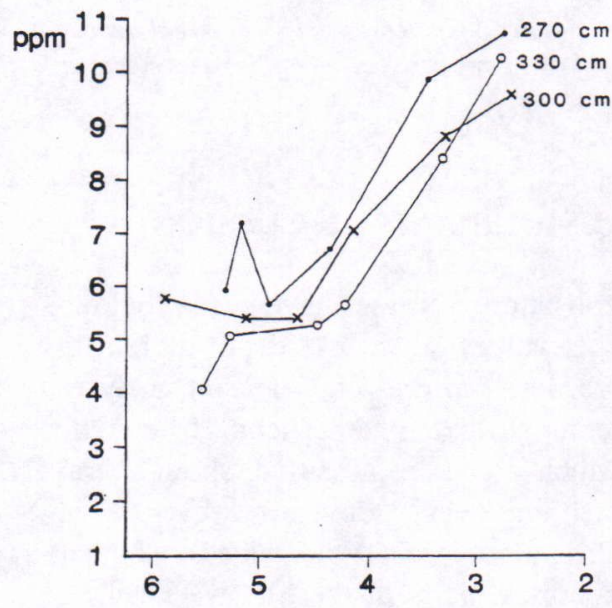

Figure 12. Dissolved $K$ versus $p H$ at different depths in the till profile at site 365 , Kaaresuvanto, Pulju moraine.

$\mathrm{pH}$

$\mathrm{pH}$

down. Pronounced leaching commonly takes place around $\mathrm{pH} 4$, and $\mathrm{Ca}$ is leached even around $\mathrm{pH} 3$ -3.5 . This could be due to a coating of other mineral matter around the $\mathrm{Ca}$ mineral grains, preventing the leaching processes before the $\mathrm{pH}$ level at which the coating itself will be dissolved. It can be suggested that this kind of coating may be that of hydrous $\mathrm{Al}$ and $\mathrm{Fe}$ oxides. Aluminium and $\mathrm{Fe}$ liberated from the upper parts are precipitated deeper down, especially around the $\mathrm{Ca}$-and $\mathrm{Mg}$ rich mineral grains, because the $\mathrm{pH}$ is higher very near the surfaces of these minerals. Manganese commonly has also been leached out from the upper parts (Figs. 14-15), but re-precipitated in places, as the results from Korppikangas show (Fig. 15). Zinc shows in the same time an enrichment into the hydrous $\mathrm{Mn}$ oxides. Usually $\mathrm{Cu}$ and $\mathrm{Zn}$ show no systematic trend in the analyses (Figs. 16-17), but some concentration of $\mathrm{Zn}$ into upper layers can be seen in places. 

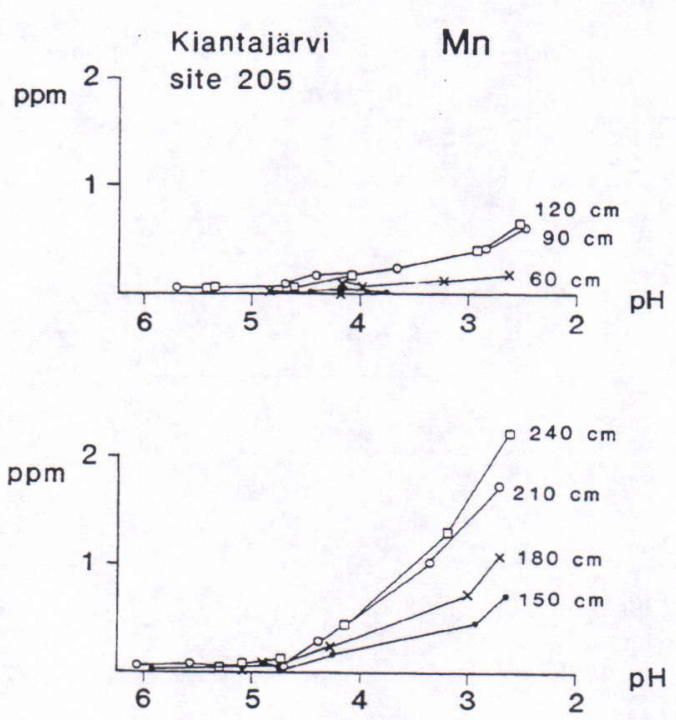

Figure 14. Dissolved Mn versus $\mathrm{pH}$ at different depths in the till profile at site 205, Kiantajärvi morainic hummock.
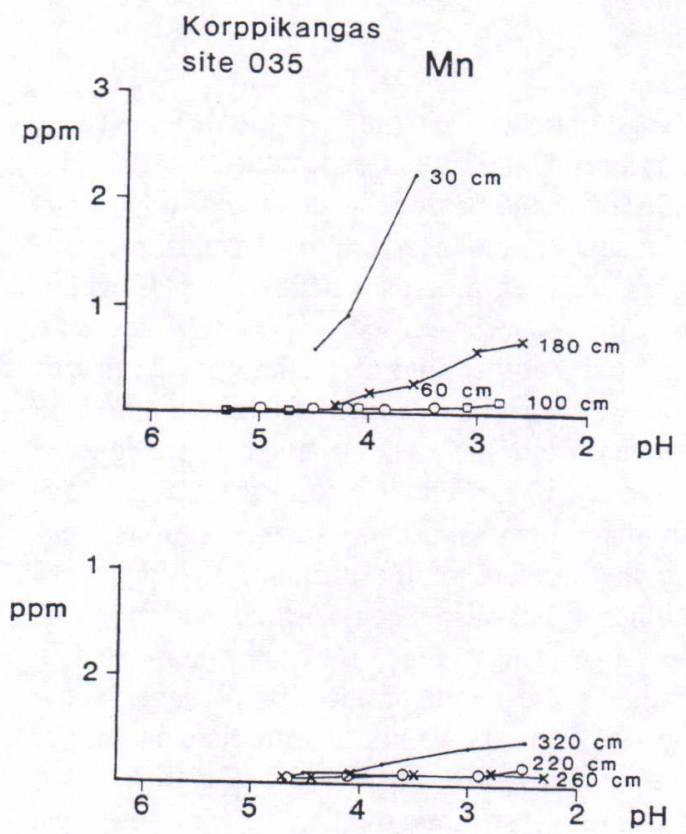

Figure 15. Dissolved Mn versus $\mathrm{pH}$ at different depths in the till profile at site 35, Korppikangas end moraine hill. The higher amount of Mn at the depth of $30 \mathrm{~cm}$
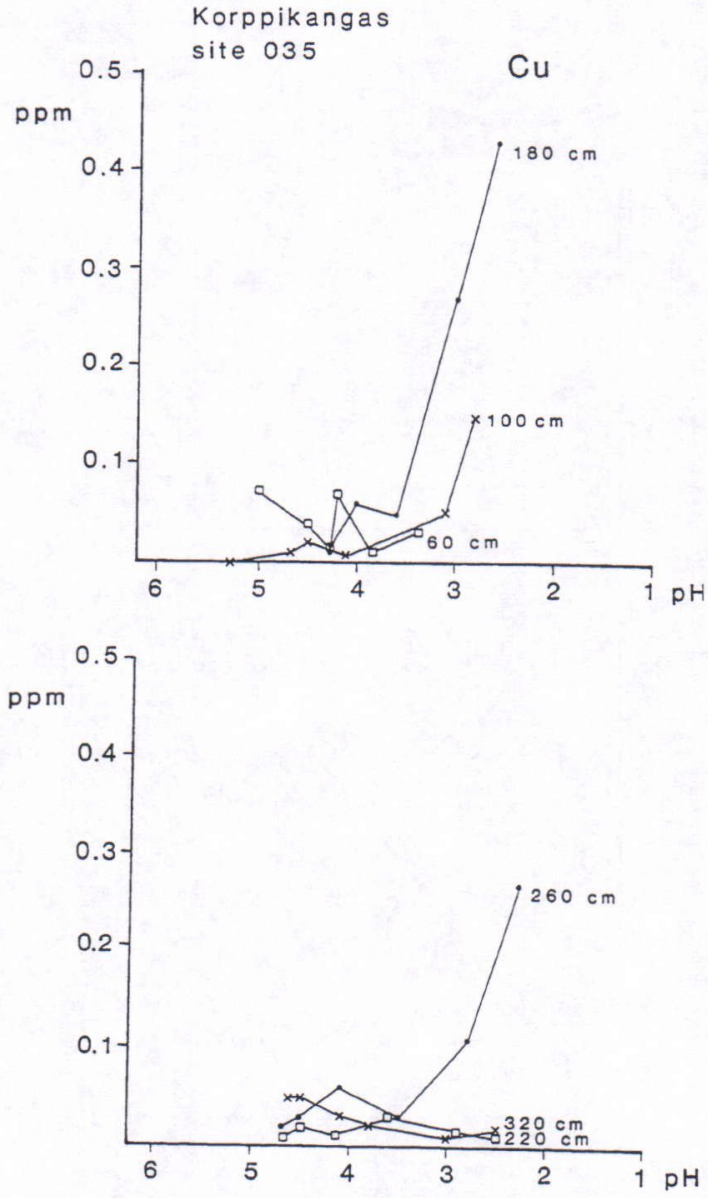

Figure 16. Dissolved $\mathrm{Cu}$ versus $\mathrm{pH}$ at different depths in the till profile at site 35, Korppikangas end moraine hill.

\section{CONCLUSIONS AND DISCUSSION}

The podzolisation processes have generally lowered the $\mathrm{pH}$ values down to a depth of $1 \mathrm{~m}$ in the till profiles, and the total element analyses show alterations to the same depth. The ANC values, which are more sensitive, show alterations which go deeper down, however, even below $2 \mathrm{~m}$ in places. The ANC values are higher in the uppermost parts of the till layers, where they represent the fast-working part of the neutralizing capacity and are attributable to the presence of hydrous $\mathrm{Al}$ and $\mathrm{Fe}$ oxides. Aluminium 

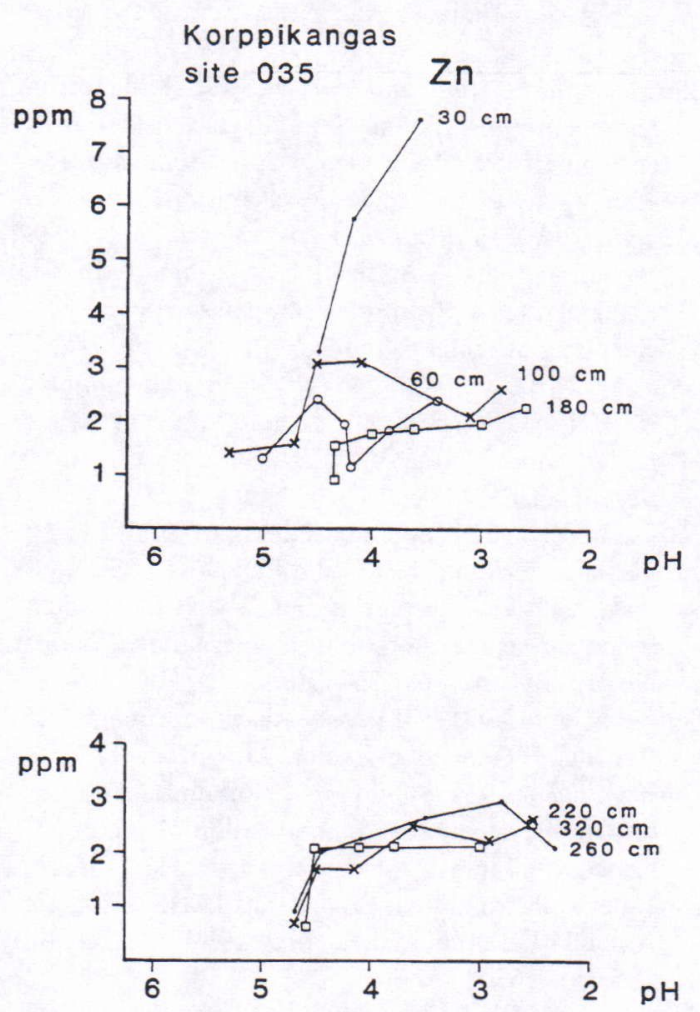

Figure 17. Dissolved $\mathrm{Zn}$ versus $\mathrm{pH}$ at different depths in the till profile at site 35, Korppikangas end moraine hill. In this case an enrichment of $\mathrm{Zn}$ has taken place in the upper part.

and $\mathrm{Fe}$ are dissolved from the upper parts of the tills in greater quantities and at a higher $\mathrm{pH}$ than deeper down (cf. Kennedy, 1986, p. 156). Magnesium, $\mathrm{Ca}, \mathrm{K}$ and $\mathrm{Sr}$ have been leached out from the upper parts as a result of postglacial weathering, and Mn has also commonly been leached out, but it has been re-precipitated in places. Copper and $\mathrm{Zn}$ show no systematic trend in the analyses, but in some places enrichment into hydrous $\mathrm{Fe}$ and $\mathrm{Mn}$ oxides can be seen. When looking at the results, one should consider the different general groups of buffering reactions which exist in tills (cf.Ulrich, 1982; Alcamo et al., 1985):

\begin{tabular}{ll} 
Buffer ranges & typical $\mathrm{pH}$ \\
\hline Carbonate buffer range & $8.0-6.2$ \\
Silicate buffer range & $6.3-5.0$ \\
Cation exchange buffer range & $5.0-4.2$ \\
Aluminium buffer range & $4.2-3.0$ \\
Iron buffer range & $<3.8$
\end{tabular}

Stress rates under natural conditions are usually low in Finland. Even though the buffering rates corresponding to some of the above buffer ranges can also be considered very low under these conditions, the buffers at each $\mathrm{pH}$ level are mostly able to neutralize the whole acid deposition. The lower $\mathrm{pH}$-level buffers, do not predominantly start working before the higher ones have been exhausted (cf. Hettelingh and Hordijk 1987, p.45).

The present experiments more or less resemble acid rain conditions. Acid rain occurs commonly in Finland, but not all rain is equally acid (e.g. Järvinen and Haapala, 1980). Acid stress rates can be very high at times and the higher $\mathrm{pH}$-level buffers are often unable to neutralize the acidity immediately, so that the lower $\mathrm{pH}$-level buffering processes come into play. It seems that the critical soil $\mathrm{pH}$ level and related high amount of dissolved elements, some of them harmful (e.g. Al), which cause forest damage, can often be reached in these highly acid showers, and the surface waters also will suffer. However, the total buffering capacity of a thick till sequence is high (cf. Shilts et al., 1981, Shilts, 1984a,b), and the slowly percolating water will be buffered before reaching the groundwater table or soon afterwards. The groundwater is therefore not greatly endangered in areas with thick till deposits.

ACKNOWLEDGEMENTS: This work (SOMAproject) has been financed by the Finnish Academy. Analyses have been done in the geochemical laboratory of the Department of Geology. Mrs. Kristiina Karjalainen has drawn the figures. Mr. Malcolm Hicks, M.A., checked the English of the manuscript. The authors express their gratitude to all the institutions and persons involved. 


\section{REFERENCES}

Aario, R., 1984. The origin and properties of morainic landforms in northern Finland, with special reference to their potential range of use. Määräaikainen loppuraportti Suomen Akatemian tutkimusprojektissa 04-114. Oulu (in Finnish).

Aario, R., 1990. Morainic landforms in Northern Finland. In: R. Aario (Ed.), Glacial Heritage of Northern Finland. Nordia Tiedonantoja A 1, pp 13-27.

Aario, R. and Peuraniemi, V. 1991a. Average trends of till acidification. Geol. Surv. Finland. Special Paper 9, pp. 21-28.

Aario, R. and Peuraniemi, V. 1991b. Moreenin happamoitumisesta. Geol. Surv. Finland, Report of Investigation 105, pp. 17-30.

Alcamo, J., Kauppi, P., Posch, M., Runca, E., 1984. Acid rain in Europe: a framework to assist decision making. Working Paper WP-84-32, International Institute for Applied Systems Analysis, Laxenburg, Austria, April 1984.

Derome, J., 1989. Cation mobility in forest humus and uppermost mineral soil layers. In: E. Pulkkinen (ed.), Symposium on environmental geochemistry in northern Europe. Abstracts, pp. 14-15.

Hettelingh, J-P and Hordijk, L., 1986. Environmental conflicts: The case of acid rain in Europe. Annals of Regional Science, 20, pp 38-52.

Järvinen, O. and Haapala, K., 1980. Sadeveden laatu Suomessa 1971-1977; English Summary: The quality of wet and dry deposition in Finland according to observations made from 1971 to 1977. Vesihallitus - National Board of Waters, Finland. Report 198, pp. 1-101.

Kennedy, I.R., 1986. Acid soil and acid rain. The impact on the environment of nitrogen and sulphur cycling. Res. Stud. Press Ltd. England.

Olsson, M. and Melkerud, P.A., 1989. Quantification of chemical weathering. In: E. Pulkkinen (ed.), Symposium on environmental geochemistry in northern Europe. Abstracts, pp. 14-15.

Ottesen, R. T., Volden, T. and Wolden, O., 1989. Tolerance of Norwegian overburden to acid rain. In: E. Pulkkinen (ed.), Symposium on environmental geochemistry in northern Europe. Abstracts, p. 5.

Petäjä-Ronkainen, A., Peuraniemi, V. and Aario, R., 1992. On podzolization in glaciofluvial material in Northern Finland. Ann Acad. Sci. Fennicae A. III. 156,19 p.

Räisänen, M. L. and Lahermo, P., 1985. Maaperän happamoitumistutkimuksiin soveltuvista osittaisuuttomenetelmistä. Geol. Surv., Finland. Researches in Environmental Geochemistry 2, pp. 1-63.

Räisänen, M. L., Pulkkinen, E. and Kontio, M., 1989. Weathering and acidification in Finland. In: E. Pulkkinen (ed.), Symposium on environmental geochemistry in northern Europe. Abstracts, pp. 7-8.

Shilts, W.W., Card, K.D., Poole, W.H. and Sanford, B.W., 1981. Sensitivity of bedrock to acid precipitation: modification by glacial processes. Geol. Surv. Canada, Paper 81-14

Shilts, W.W., 1984a. Potential effects of acid rain on glaciated terrain. In: R.G. La Fleur (ed.), Groundwater as a Geomorphic Agent. The Binghampton Symposia in Geomorphology. International Series No. 13, 390 p., pp. 135-156.

Shilts, W.W., 1984b. Till geochemistry in Finland and Canada. J. Geochem. Explor. 21, pp. 95-117.

Soveri, Jouko, 1989. Acid percolation and disintegration, transformation and mobilization of some substances in Finnish Quaternary deposits. Groundwater Contamination. Proc. Third IAHS Scientific Assembly, Baltimore, MD, May 1989. IAHS Publ. 185, pp. 163-170.

Ulrich, B., 1982. Soil acidity and its relation to acid deposition. In: B. Ulrich and J. Pankrath (eds.), Effects of accumulation of air pollutants in forest ecosystems. Workshop Proceedings, Göttingen, FRG, May 16-19, 1982, pp. 127-146.

Vuorinen, A. and Lahermo, P., 1987. The role of Fe oxy-hydroxides in formation of the acid neutralization capacity in soils. In: R. Perry, R.M. Harrison, J.N.B. Bell and J.N. Lester (eds.) Acid rain: scientific and technical advances. Publ. Div., Selper Ltd., London.

Wilson, M. J., 1986. Mineral weathering processes in podzolic soils on granitic materials and their implications for surface water acidification. J. Geol. Soc., 143, pp. 691-697.

Wyatt, P.H., 1984. A technique for determining the acid neutralizing capacity of till and other surficial sediments: Current Research, Part A, Geol. Surv. Canada, Paper 84-1A, pp. 597-600. 